\title{
KNOWLEDGE AND HEALTH-BELIEF AS PREDICTOR OF PREVENTION AND MANAGEMENT OF CHILDHOOD DIARRHOEA AT FEDERAL MEDICAL CENTRE, OWO
}

\section{Ogunmiluyi Omowumi Mary and Ademola Amosu}

\author{
School of Public Health and Allied Health, Babcock University Ilishan Remo.
}

Cite this article:

Ogunmiluyi O.M., Ademola A. (2021), Knowledge and Health-Belief as Predictor of Prevention and Management of Childhood Diarrhoea at Federal Medical Centre, Owo. International Journal of Public Health and Pharmacology 1(1), 43-61. DOI: 10.52589/IJPHP67H4UXS8.

\section{Manuscript History}

Received: 10 May 2021

Accepted: 28 May 2021

Published: 12 June 2021

Copyright $\odot 2020$ The Author(s). This is an Open Access article distributed under the terms of Creative Commons Attribution-NonCommercialNoDerivatives 4.0 International (CC BY-NC-ND 4.0), which permits anyone to share, use, reproduce and redistribute in any medium, provided the original author and source are credited.

\begin{abstract}
Childhood diarrhoea is found to be the second main cause of under-five mortality the world over, in the developing countries. Therefore, the study examines the health beliefs of mothers as predictors of prevention and management of childhood diarrhoea in Federal Medical Centre, Owo, Ondo State. The study employs a descriptive cross-sectional survey research, a consecutive sampling technique to select 166 mothers of under-five children at the Children Outpatient Clinic of FMC, Owo. A mixed method analysis of quantitative and in-depth interviews was utilized to retrieve information from mothers of under-five children in FMC, Owo. The demographic information and research question was analysed using descriptive statistics while the research hypothesis was analysed using Pearson Product Moment Correlation and Linear regression. The results revealed that, more than half of the mothers have average knowledge of childhood diarrhoea. Across all the factors, there was a moderate level of health belief in the prevention of childhood diarrhoea among the nursing mothers of under-five children. $66.5 \%$ Average level of management of childhood diarrhoea. The first hypothesis indicated a significant relationship of socio-demographic characteristics and prevention of childhood diarrhoea among nursing mothers in underfive children in FMC, Owo Marital Status, 0.625, Occupation, 0.788, income of mother, 0.911, ethnicity, 0.771 and level of education, 0.604) and the prevention of childhood diarrhoea, this was significant 0.05 level of significance. However, religion was not significantly related with the prevention of childhood diarrhoea and prevention of childhood diarrhoea among nursing mothers of under-five children in FMC, Owo $(p>0.05)$. There was a significant relationship between knowledge and management of childhood diarrhoea among nursing mothers of underfive children in FMC, Owo $(r=0.779, d f=165, p<0.05)$. The study recommends that there is a need for public health physicians, social workers to provide nutritional educational programs about diarrhoea should be implemented for mothers in different community health services. Government should enforce good sanitation and improvement of housing conditions, especially water resources in rural areas.
\end{abstract}

KEYWORDS: Health-Belief, Childhood Diarrhoea, Nursing Mothers, Medical Centre, Nigeria 


\section{INTRODUCTION}

Childhood stage of development is characterized by near-total dependence by the children on adults and health care services provided by them. Under-five children constitute an important population group in terms of vulnerability to health conditions that could adversely affect their health and well-being. Diarrhoeal disease is a major public health problem that results in illness and death among infants and young children in low-income countries (Kotlof, 2019).

In last 25 years, a significant reduction in the Maternal, Neonatal and Child mortality rate occurred throughout the globe, but a negligible progress in reducing the Maternal, Neonatal and Child mortality rate was observed in Nigeria (Abass, 2017; UNICEF, 2019; Arulogun, 2018). During the year 1990, the under 5 mortality rate of children in Nigeria was 138.6 per 1000 live births, that was reduced to 112.3 in 2000 and 81.1 in 2015 per 1000 live births. Similarly, the infant mortality rate of Nigeria in 1990 was 106.1 per 1000 live births, which reduced to 87.7 in 2000 and 65.8 in 2015 per 1000 live births (UNICEF, 2019; Adebayo, 2018). Therefore, despite a significant reduction in under 5-year children and infant mortality rate, Nigeria still ranks among top 25 countries with highest infant mortality rates (WHO/UNICEF, 2019; Adebayo, 2018).

Research in Nigeria displayed that the majority of mothers had poor understanding of the causes of diarrhoea in under-five children and only $9.9 \%$ used ORS in treatment of diarrhoea (Arulogun, 2018). These findings indicated poor management of diarrhoea by mothers in particular areas. Mothers usually delay, seeking medical advice about diarrhoea. Sometimes it is too late and the child is either already dehydrated or has started to lose weight. Therefore, it is imperative to notice and identify certain symptoms or signs in order to seek medical advice promptly (WHO, 2018; UNICEF, 2019).

Diarrhoeal diseases result from the additive effects of health belief and cultural factors including improper child feeding practices. Widely held traditional beliefs play a significant role in the daily lives and health of the Ondo people in the rural area, and are likely to determine the way caregivers perceive and respond to illnesses such as childhood diarrhoea. Concepts and terminologies for illnesses and their signs and symptoms used by medically trained health workers do not necessarily mean the same for mothers or other caregivers. On the other hand, caregivers may use local words and concepts that do not translate simply into medical terms. For these reasons languages and beliefs may not only influence healthcare seeking behaviour but may also lead to misunderstandings during medical consultations, health promotion activities, and health surveys (Kramer, 2019; Andrade, 2019).

Behavioral factors mean unhygienic behaviors of the children and/or of the mothers or any person caring for the children in daily routines. Environmental factors included poor sanitation, poor domestic hygiene, and unavailable access to clean water. Furthermore, Mansur, (2017) noted that the socioeconomic vulnerability of families living around the river (delta and estuary areas) could increase the exposure to disease risks, especially in times of floods. This is in addition to environmental factors (climate) and belief, prevention and management of disease outbreaks (Breurec, 2017).

The perceived barrier to management of childhood diarrhoea is related to the emerging poor socioeconomic status of families and has served as one of the lead cause of illness condition and even death than moderate- and high-income families; they also cannot modify or create a 
better environment for living to avoid the development of disease in their area. Diarrhoea, measles, and pneumonia are environmentally based diseases, and hence, environmental factors are the most crucial in influencing disease (Solar, 2017; Suk, 2016)

Since diarrhoea is the common cause of child death in Nigeria, the situation of childhood diarrhea in Owo is on the increase as presentation of children in the hospital is associated with poor hygiene practice of mothers. Nursing mothers of under-five children often complain of non-availability of clean and affordable water in the rural communities, hence they opt for water from the streams. This situation has precipitated the increasing presentation of diarrhoea among under-five children at the Federal Medical Centre, Owo. It is also observed that in rural areas the education level of mothers is poor due to which they do not know about the diarrhoeal disease, their prevention and home management as result the morbidity due to diarrhoeal increase. The thrust of this study is to examine the knowledge and health-belief of mothers toward management of childhood diarrhoea in Federal Medical Centre, Owo, Ondo State.

\section{Research Objectives}

The overall objective of the study is to examine the knowledge and health-belief of mothers toward management of childhood diarrhoea in Federal Medical Centre, Owo, Ondo State

1. Ascertain the level of knowledge of nursing mother about childhood diarrhoea in underfive children in FMC, Owo

2. examine is the health belief of prevention of mothers of under-five children about childhood diarrhoea in FMC, Owo

3. investigate is the management of childhood diarrhoea in under-five children among nursing mothers in FMC, Owo among nursing mothers.

\section{Research Questions}

1. What is the level of knowledge of nursing mother about childhood diarrhoea in underfive children in FMC, Owo

2. What is the health belief of prevention of mothers of under-five children about childhood diarrhoea in FMC, Owo

3. What is the management of childhood diarrhoea in under-five children among nursing mothers in FMC, Owo among nursing mothers

\section{Methods and Designs}

\section{Research Design}

The study employed a descriptive cross-sectional survey research. Basis for considering a cross-sectional study that provides sufficient information about the research problem, best strategies towards addressing the problems of diarrhoea in under-five children of FMC, Owo, Ondo State. Descriptive survey research is considered appropriate for kind of study because, it is quantitative and also provide answers to the research question and enquiry of interest to the researcher and it provide information about phenomena or relationships among phenomena (Adejana, 2015). 


\section{Population}

\section{Description of Study Population Area}

The Federal Medical Centre, Owo, Ondo States was formerly General Hospital at Owo owned by the Ondo State. Government was taken over by the Federal Government of Nigerian in 1989.

The Federal Medical Centre (FMC) Owo is one of the pioneer FMCs established in 1993 by the Federal Government. FMC Owo provides tertiary healthcare services in Ondo State. The hospital is a 300 bedded hospital with staff strength of 1,325 out of which doctors and nurses constitute about 500. FMC Owo is one of the two hospitals providing tertiary care in Ondo State and has the largest volume of patient attendance in the state. FMC Owo provides primary, secondary and tertiary level of care. The hospital's vision is to provide qualitative, affordable and accessible healthcare services to all. The centre serves to provide healthcare for the people in the catchment areas which comprise the entire Ondo State and neighbouring Osun, Ekiti, Edo, Kogi and Lagos States. The hospital also serves people in transit as it is located 400meters away from the highway that links Abuja to Lagos, and so gives care to diverse people from other parts of the country. The hospital provides services in different specialties such as Family Medicine, Internal Medicine, Surgery, Obstetrics and Gynaecology, Community Health, Dentistry, Ophthalmology as well as Psychiatry. Others include Laboratory Medicine, Radiology, Physiotherapy, Social/Welfare services. FMC Owo also offers residency training programmes in General Surgery, Orthopaedic Surgery,Medicine, Paediatrics, Obstetrics and Gynaecology, Psychiatry and Community Medicine.

The Children Outpatient Clinic has consultants and registrars who offer comprehensive, coordinated and undifferentiated healthcare in out-patient, emergency and staff medical services to all individuals children under the age of 14years presented in the children Outpatient clinic. The Children Outpatient Clinic attends to ambulant patients on all days of the week. The consultation times are between 8:00am and 4pm on weekdays and 8:00am to 2:00pm on Saturday and Sunday including public holidays. After necessary registration at the records unit, clients are sent to the clinic reception area for health talks, screening and vital signs measurements by the nurses. Both new and old patients are attended to by Pediatrician. The CHOP clinic had an average patient attendance of 60daily and reduced numbers on Saturday and Sundays to make an average of 1275 patients monthly, with an average of 54 new children with diarrhea seen in the children outpatient clinic of the hospital.

\section{Sample size and sampling Technique}

\section{Sample Size Determination}

The required sample size was calculated by using the Leslie-Kish, (1965) formula for estimating sample size

$$
\mathrm{N}=\frac{\underline{\mathrm{Z}}^{2}}{\underline{\mathrm{P}}} \underline{\mathrm{P}(1-\mathrm{P})}
$$




\section{Where,}

$\mathrm{N}=$ minimum sample size

$\mathrm{P} \quad=\quad$ the estimated prevalence of value, $12 \%$ of under-five children are with diarrhoea in Ibadan, University College Hospital, Ibadan (Ademola, et al, 2018)

$\mathrm{D}=$ the absolute precision of the study which is 0.05

$\mathrm{Z}=$ area under normal curve corresponding to $95 \%$ confidence interval. $=\quad 1.96$

Therefore,

$$
\begin{aligned}
& \mathrm{N}=\underline{(1.96)^{2}} \times \underline{0.12 \times(1-0.12)} \\
& 0.05^{2} \\
& \mathrm{~N}=\underline{3.92 \times 0.12 \times 0.88} \\
& 0.0025 \\
& \mathrm{~N}=\underline{0.4139} \\
& 0.0025 \\
& \mathrm{~N}=166 \text { nursing mother with under-five children will be selected for } \\
& \text { the study over a period of three months }
\end{aligned}
$$

\section{Sampling Technique}

The study used a consecutive sampling technique to select 166 mothers of under-five children that are presented at the children's out-patient clinic of FMC, Owo. Each month, an average of 54 newly registered patients are seen monthly at the Children Outpatient Clinic of FMC, Owo.

During the two months period of the study, $(54 \times 2)=108$ under-five children with diarrhoea will be expected to present at the Children Outpatient Clinic of FMC, Owo.

Since the sample size is 166 , the sample interval is $(166 / 108)=2$. Thus, one in every two mothers of under-five children with diarrhoea was recruited for the study.

\section{Instrumentation}

The research instrument for the study was a questionnaire with the mothers. The questionnaire tagged: Individual Characteristics, Knowledge of Causes, Prevention and Management of Diarrhea in Under-five Children. The structured questionnaire shall be made up of four sections viz $\mathrm{A}-\mathrm{D}$

Section A:- Measure of Demographic characteristics: This consists of items question that shall be self-constructed about the demographic characteristics(age, gender, sex, monthly income of parent, Tribe and religion of family of the nursing mother) 
Section B -Knowledge of Childhood diarrhoea: This consists of items questions developed by the researcher to measure the knowledge of diarrhoea in children. The respondents asked to respond to a two point scale ranging from Yes and No.

Section C -Health-Belief Childhood diarrhoea: This consists of items questions developed by the researcher to address around personal disposing factors, reinforcing factors and enabling factors for the prevention of childhood diarrhoea. The respondents were asked to respond to a two point scale ranging from Strongly Agree to Strongly Disagree

Section D - Management Childhood diarrhoea: This consists of questions developed by the researcher which are open-ended to examine the management of childhood diarrhea in underfive children. The respondents were asked to respond to a two point scale ranging from Strongly Agree to Strongly Disagree

\section{Validity and Reliability of Instrument}

Validity: The instruments for data collection were subjected to face and content validity. The items in the questionnaire were presented to experts in the test and measurement in the department of public health for review, corrections and appraisal after which necessary corrections were made. For the face validity, experts indicated that the instrument has facial relevance and acceptability to what it claims to measure as it was also subjected to face validity among colleagues in the nursing department.

In ensuring the content validity, the experts consulted ensure the appropriateness of the content of the instrument. Experts will also ensure that the items in the questionnaire adequately the concepts being measured by the subject matter it was designed to measure thereby confirming its content validity with the help of the project supervisor and other experts from the School of Public health. Face validity of the instrument was needed to ensure that the items on the instrument actually addressed the objectives of the study and content validity to ensure that it measures what it is intended to measure accurately.

Reliability: An instrument can be said to be reliable if the instrument consistently measures what it is intended to measure (internal consistency). In this study, reliability of the questionnaire will be determined by pre-testing the questionnaire among a population of similar characteristics as the study sample with 20 respondents and the data obtained was analysed using test statistics of Cronbach's reliability score.

\section{Method of Data Collection}

Data will be collected during clinic hours of the Children Out-patient Clinic of FMC, Owo. Approval to conduct the study was obtained by the Ethics and Research Committee of the hospital. The author will recruit the services of two female research assistants to assist with the administration of the questionnaire. They were trained on the need for confidentiality and privacy of the respondents, adequate administration of the questionnaire and effective communication skills with the respondents. They were fluent in English and Yoruba languages to aid in communication during administration of the questionnaire.

After the research assistants must ascertain that the nursing mothers met the inclusion criteria, they informed the respondents of the study and subsequently directed them to the researcher who utilized the adjacent consulting room for administration of the questionnaire. Nursing 
mothers who met the inclusion criteria and provided consent were served the questionnaire constructed in English language. All correctly filled questionnaires were returned to the researcher immediately which will be verified for accuracy.

\section{Method of Data Analysis}

Data entry was done using SPSS statistical package version 28 , followed by data cleaning, coding, and editing for final analysis. Frequency tables for all questions were used to identify missing information, detecting entry errors, and checking for inconsistencies such as outliers. The statistical analysis was done through descriptive and inferential analysis. The selected socio-demographic variables were analysed using the descriptive analysis. Knowledge, practice, and individual characteristics questions were analysed using descriptive statistics involving rating scale, where aggregated mean scores were derived and categorised accordingly.

\section{Ethical Consideration}

Approval was obtained from the FMC Owo Hospital's health research ethics committee and the Babcock University Health and Research Ethical Committee (BUHREC). Informed written consent was obtained from each of the nursing mothers before administering the questionnaire and a high level of privacy was ensured. Moreover, the need for confidentiality and respect of privacy of the respondents was stressed to the research assistants during their training. Serial numbers were used on the questionnaire instead of the names of respondents in order to ensure confidentiality, and this was maintained throughout and even after the study was completed, by keeping the data secured and made available only to members of the research team. Furthermore, respondents were adequately informed that they had the right to decline participation or to withdraw from the study at any point in time. In addition, respondents were informed that refusal to participate in the study or withdrawal from it would not result in any loss of benefits or penalty. The participants were informed that the results of the study would contribute positively to the care of the under-five children in the hospital.

\section{RESULTS}

\section{Socio-demographic Characteristics of Respondents}

A total of four hundred $(\mathrm{n}=166)$ nursing mothers of under-five children in FMC, Owo, Nigeria, participated in the study for a period of 3 weeks, between March and April, 2021. The frequency distribution table (Table 1) shows the socio demographic and reproductive characteristics of the respondents. Majority of the children who participated in the study are female $(60.8 \%)$ while $39.2 \%$ are male.

The mean age of the children $2.23 \pm 1.39,61.4 \%$ of the children are between 0 to 4 months, $24.1 \%$ are between $5-12$ months while $24.1 \%$ are between $1-5 y$ years. Majority of the mothers $83.1 \%$ are married while $16.9 \%$ of the respondents are single. While $8.4 \%$ of the mothers of under-five children are civil servants, $13.3 \%$ of the respondents are unemployed, $10.2 \%$ are Artisan, $32.5 \%$ of the participants are in other occupations while $35.5 \%$ are traders. 
Among the nursing mother of under-five children, $30.7 \%$ earn less than 100,000 Naira, $36.7 \%$ earn between $100,000-200,000$ while $32.5 \%$ earn above 200,000 Naira. $63.3 \%$ of the respondents are Christain by faith while $36.7 \%$ are Muslim. Furthermore, $64.5 \%$ of the mothers are from monogamous family settings, while $35.5 \%$ are from the Polygamous family settings. Majority of the participants are predominantly from the Yoruba ethnic group while $16.9 \%$ are from Igbo ethnic group. Over half of the mother $50 \%$ had primary education, $28.3 \%$ had secondary school education, $14.5 \%$ had no formal education while $7.2 \%$ had tertiary education.

Table 1: Socio-demographic characteristics of mothers $(\mathrm{N}=166)$

\begin{tabular}{|c|c|c|}
\hline Socio-demographic Characteristics & Frequency & Percentage \\
\hline $\begin{array}{l}\text { Sex of the child } \\
\text { Male } \\
\text { Female }\end{array}$ & $\begin{array}{c}65 \\
101\end{array}$ & $\begin{array}{l}39.2 \\
60.8 \\
\end{array}$ \\
\hline $\begin{array}{l}\text { Age of the child } \\
0-4 \text { months } \\
\text { 5-12months } \\
1-5 \text { years }\end{array}$ & $\begin{array}{c}102 \\
24 \\
40 \\
\end{array}$ & $\begin{array}{l}61.4 \\
14.5 \\
24.1 \\
\end{array}$ \\
\hline $\begin{array}{l}\text { Marital Status of Mother } \\
\text { Single } \\
\text { Married }\end{array}$ & $\begin{array}{c}28 \\
138\end{array}$ & $\begin{array}{l}16.9 \\
83.1 \\
\end{array}$ \\
\hline $\begin{array}{l}\text { Occupation of mothers } \\
\text { Civil servants } \\
\text { Unemployed } \\
\text { Artisan } \\
\text { Others } \\
\text { Trading } \\
\end{array}$ & $\begin{array}{l}14 \\
22 \\
17 \\
54 \\
59\end{array}$ & $\begin{array}{c}8.4 \\
13.3 \\
10.2 \\
32.5 \\
35.5\end{array}$ \\
\hline $\begin{array}{l}\text { Income per annum } \\
\text { less than } 100,000 \\
100,000-200,000 \\
200,000 \text { Naira above }\end{array}$ & $\begin{array}{l}51 \\
61 \\
54 \\
\end{array}$ & $\begin{array}{l}30.7 \\
36.7 \\
32.5 \\
\end{array}$ \\
\hline $\begin{array}{l}\text { Religion } \\
\text { Christain } \\
\text { Islam }\end{array}$ & $\begin{array}{c}105 \\
61 \\
\end{array}$ & $\begin{array}{l}63.3 \\
36.7\end{array}$ \\
\hline $\begin{array}{l}\text { Family settings } \\
\text { Monogamous } \\
\text { Polygamous } \\
\end{array}$ & $\begin{array}{c}107 \\
59 \\
\end{array}$ & $\begin{array}{l}64.5 \\
35.5 \\
\end{array}$ \\
\hline $\begin{array}{l}\text { Ethnicity } \\
\text { Yoruba } \\
\text { Igbo }\end{array}$ & $\begin{array}{c}138 \\
28\end{array}$ & $\begin{array}{l}83.1 \\
16.9\end{array}$ \\
\hline $\begin{array}{l}\text { Level of Education } \\
\text { No formal education } \\
\text { Primary education } \\
\text { secondary education } \\
\text { Tertiary education }\end{array}$ & $\begin{array}{l}24 \\
83 \\
47 \\
12\end{array}$ & $\begin{array}{c}14.5 \\
50.0 \\
28.3 \\
7.2\end{array}$ \\
\hline
\end{tabular}

Mean Age of participants in this study was $2.23 \pm 1.39$ years 
What is the level of knowledge of nursing mothers about childhood diarrhoea in underfive children in FMC, Owo?

The study participants were asked if they have ever heard of childhood diarrhoea among underfive years old children. Over sixty $(63.3 \%)$ have heard about diarrheal in under-five years children while $3.67 \%$ have not heard about childhood diarrhoea. Majority of the mothers $30.7 \%$ were correct that childhood diarrhoea is about frequent passing of watering stool 3 or more times, $21.7 \%$ reported frequent passing of normal stool, $18.1 \%$ report blood in the stool while $29.5 \%$ reported when a child has greenish stool.

In terms of the causes of diarrhoea in children most of the respondents $28.3 \%$ reported teething as one of the main which is correct, $24.1 \%$ reported drinking of unhygienic feeding bottle, 20.5 reported contaminated water, $10.8 \%$ also reported improper stool disposal and improper stooling. Most of the respondents were correct that $72.9 \%$ were correct that poor and hygienic toilet facilities can cause diarrhoea in children while $27.1 \%$ were not correct. However, the majority of the respondents $71.1 \%$ were correct that defecating in an open field could cause diarrhoea while $28.9 \%$ are not. $74.1 \%$ were correct that drinking raw milk could cause diarrhea in children while $25.9 \%$ were not correct. This is represented in Table 2

Table 2: Level of knowledge of nursing mother about childhood diarrhoea in under-five children in FMC, Owo

\begin{tabular}{lcc}
\hline Knowledge of Childhood Diarrheal & Frequency & Percentage \\
\hline Have you heard of Childhood Diarrhoea & 105 & 63.3 \\
Yes & 61 & 36.7 \\
No & 51 & 30.7 \\
\hline What does childhood diarrhoea mean to you & & \\
Frequent passing of watering stool 3 or more & 36 & 21.7 \\
times & 30 & 18.1 \\
Frequent passing of normal stool & 49 & 29.5 \\
Blood in stool & & \\
Greenish stool & 47 & 28.3 \\
\hline Causes of Diarrhoea in children & 9 & 5.4 \\
Teething & 40 & 20.5 \\
Evil eye & 18 & 10.8 \\
Contaminated water & 18 & 10.8 \\
Improper stool & 34 & 24.1 \\
improper stool disposal & & \\
unhygienic feeding bottle & & \\
\hline Does poor and unhygienic toilet facility cause & 121 & 72.9 \\
diarrhoea & 45 & 27.1 \\
Yes & & \\
No & 118 & 71.1 \\
\hline Does defecating in open field cause diarrhoea & 48 & 28.9 \\
Yes & & \\
No & 123 & 25.9 \\
\hline Does Drinking raw milk cause diarrhoea & 43 & \\
Yes & & \\
No & & \\
\hline
\end{tabular}




\section{Table 3: Level of Knowledge Childhood Diarrhoea $(n=166)$}

This study asked 6 questions relating to knowledge of Childhood diarrhoea among mothers of under-five children. The result presents the summary of the mother's level of knowledge of Childhood diarrhoea. The maximum score obtainable is 14 which is therefore categorized as good (11-14), moderate/average (6-10) and poor (1-5). More than half of the mothers have average knowledge of childhood diarrhoea, $30.1 \%$ had good knowledge while $11.5 \%$ had poor level of knowledge of childhood diarrhoea

\begin{tabular}{|c|c|c|c|}
\hline Category & Criteria & Frequency & $\%$ \\
\hline $11-14$ & Good & 50 & 30.1 \\
\hline $6-10$ & Average & 97 & 58.4 \\
\hline $1-5$ & Poor & 19 & 11.4 \\
\hline \multicolumn{4}{|c|}{ Mean =10.3, Std. Dev = 1.74} \\
\hline Keys: Poor: & $<50 \%$ & & \\
\hline Average: & $50-70 \%$ & & \\
\hline Good: & 71-90\%: & & \\
\hline
\end{tabular}

\section{What is the health belief of mothers (predisposing factors, reinforcing factors, enabling factors and environmental factors)?}

Table four presented reported personal predisposing factors to childhood diarrhoea, 38\% disagreed to have personal concerns about preventing diarrhea in their children as it will prevent untimely death. 34.9\% agreed that they believe washing their hands after contact with faeces can prevent diarrhea in my child. Also, 40.4\% agreed that they believe that if they can breastfeed their child well it can prevent diarrhea in their child. $41.6 \%$ reported that they believe that disposing of their child's stool properly can prevent diarrhea in their child. $33.1 \%$ of the respondents strongly agreed that their child's health is important so they take all necessary precautions for the prevention of diarrhoea in their child.

For the reinforcing factors, the majority of the respondents agreed that health care providers educate them during postnatal clinic visits about preventing child diarrhoea. Also, 39.8\% agreed that they are satisfied with the health talk given by health care providers in preventing diarrhea in their child. Majority of the mothers agreed that they practice the lecture given to them by health care providers in preventing diarrhoea in their child. Most of the mothers, $33.7 \%$ also strongly agreed that their in-laws are adequately supportive in their care. $38 \%$ of the respondents strongly agreed that their husband plays a major role in preventing diarrhoea in their child.

For the enabling factors, most of the mothers $44 \%$ strongly agreed that Hand hygiene campaigns can help to prevent childhood diarrhoea, also, $45.1 \%$ of the mothers also agreed that availability of hand hygiene products and sinks can prevent childhood diarrhoea. $38 \%$ agreed that Proper education on immunization can prevent childhood diarrhoea. $40.4 \%$ strongly agreed that they do not have enough money in taking necessary precautions of preventing diarrhoea in their child.

In terms of environmental factors, $45.2 \%$ of the respondents agreed that they ensure proper waste disposal so as to prevent diarrhoea in their child. $43.4 \%$ of the respondents disagreed that 
a latrine toilet facility can help to prevent diarrhoea in their child, also $39.2 \%$ of the respondents disagreed that Proper Sanitation can help to prevent diarrhoea in their child. Majority of the respondents $52.4 \%$ reported to give their child herbs to drink to prevent diseases like diarrhoea. Also $48.2 \%$ reported to protect the source of water to help in the prevention of diarrhoea. $57.2 \%$ of the respondents strongly agreed that they use a cup and spoon for their child to prevent diarrhoea.

Table 4 showing health of belief of the prevention of childhood diarrhoea in FMC, Owo

\begin{tabular}{|c|c|c|c|c|}
\hline Personal Predisposing Factors & $\begin{array}{l}\text { Strongly } \\
\text { Agree }\end{array}$ & Agree & Disagree & $\begin{array}{l}\text { Strongly } \\
\text { Disagree }\end{array}$ \\
\hline $\begin{array}{l}\text { I have personal concerns about } \\
\text { preventing diarrhoea in my child will } \\
\text { prevent untimely death }\end{array}$ & $38(22.9 \%)$ & $33(19.9 \%)$ & $63(38 \%)$ & $32(19.3 \%)$ \\
\hline $\begin{array}{l}\text { I belief washing my hands after contact } \\
\text { with faeces can prevent diarrhoea in my } \\
\text { child }\end{array}$ & $54(32.5 \%)$ & $58(34.9 \%)$ & $36(21.7 \%)$ & $18(10.8 \%)$ \\
\hline $\begin{array}{l}\text { I belief if I breastfeed my child well can } \\
\text { prevent diarrhoea in my child }\end{array}$ & $38(22.9 \%)$ & $67(40.4 \%)$ & $49(29.5 \%)$ & $12(7.2 \%)$ \\
\hline $\begin{array}{l}\text { I belief if I dispose my child's stool } \\
\text { properly can prevent diarrhoea in my } \\
\text { child }\end{array}$ & $23(13.9 \%)$ & $69(41.6 \%)$ & $37(22.3 \%)$ & $7(4.2 \%)$ \\
\hline $\begin{array}{l}\text { My child's health is important so I take } \\
\text { all necessary precaution for the } \\
\text { prevention of diarrhoea in my child }\end{array}$ & $55(33.1 \%)$ & $36(21.7 \%)$ & $45(27.1 \%)$ & $30(18.1 \%)$ \\
\hline \multicolumn{5}{|l|}{ Reinforcing factors } \\
\hline $\begin{array}{l}\text { The health care providers educate me } \\
\text { during postnatal clinic visit about } \\
\text { preventing child diarrhoea }\end{array}$ & $81(48.8 \%)$ & $67(40.7 \%)$ & $12(7.2 \%)$ & $6(3.6 \%)$ \\
\hline $\begin{array}{l}\text { I am satisfied with the health talk given } \\
\text { by health care providers in preventing } \\
\text { diarrhoea in my child }\end{array}$ & $66(39.8 \%)$ & $62(37.3 \%)$ & $32(19.3 \%)$ & $6(3.6 \%)$ \\
\hline $\begin{array}{l}\text { I practice the lecture given to me by } \\
\text { health care providers in preventing } \\
\text { diarrhoea in my child }\end{array}$ & $70(42.2 \%)$ & $48(28.9 \%)$ & $18(10.8 \%)$ & $30(18.1 \%)$ \\
\hline $\begin{array}{l}\text { My in-laws are adequately supportive in } \\
\text { the care }\end{array}$ & $56(33.7 \%)$ & $35(21.1 \%)$ & $54(32.5 \%)$ & $21(12.7 \%)$ \\
\hline $\begin{array}{l}\text { My husband play a major role in } \\
\text { preventing diarrhoea in my child }\end{array}$ & $63(38 \%)$ & $45(27.1 \%)$ & $40(24.1 \%)$ & $18(10.8 \%)$ \\
\hline \multicolumn{5}{|l|}{ Enabling factors } \\
\hline $\begin{array}{l}\text { Hand hygiene campaigns can help to } \\
\text { prevent childhood diarrhoea }\end{array}$ & $73(44 \%)$ & $51(30.7 \%)$ & $24(14.5 \%)$ & $18(10.8 \%)$ \\
\hline $\begin{array}{l}\text { Availability of hand hygiene products } \\
\text { and sinks can prevent childhood } \\
\text { diarrhoea }\end{array}$ & $76(45.8 \%)$ & $36(21.7 \%)$ & $39(23.5 \%)$ & $15(9 \%)$ \\
\hline $\begin{array}{l}\text { Proper education on immunization can } \\
\text { prevent childhood diarrhoea }\end{array}$ & $55(33.1 \%)$ & $63(38 \%)$ & $33(19.9 \%)$ & $15(9 \%)$ \\
\hline
\end{tabular}




\begin{tabular}{|l|l|l|l|l|}
\hline $\begin{array}{l}\text { I don't have enough money in taking } \\
\text { necessary precautions of preventing } \\
\text { diarrhoea in my child }\end{array}$ & $67(40.4 \%)$ & $36(21.7 \%)$ & $57(34.3 \%)$ & $6(3.6 \%)$ \\
\hline $\begin{array}{l}\text { Environmental and behavioural } \\
\text { Factors }\end{array}$ & & & & \\
\hline $\begin{array}{l}\text { I ensure proper waste disposal so as to } \\
\text { prevent diarrhoea in my child }\end{array}$ & $75(45.2 \%)$ & $67(40.4 \%)$ & $24(14.5 \%)$ & $0(0 \%)$ \\
\hline $\begin{array}{l}\text { A latrine toilet facility can help to } \\
\text { prevent diarrhoea in my child }\end{array}$ & $61(36.7 \%)$ & $72(43.4 \%)$ & $21(12.7 \%)$ & $12(7.2 \%)$ \\
\hline $\begin{array}{l}\text { Proper Sanitation can help to prevent } \\
\text { diarrhoea in my child }\end{array}$ & $65(39.2 \%)$ & $65(39.2 \%)$ & $24(14.5 \%)$ & $12(7.2 \%)$ \\
\hline $\begin{array}{l}\text { I give my child herbs to drink to prevent } \\
\text { diseases like diarrhoea }\end{array}$ & $56(33.7 \%)$ & $87(52.4 \%)$ & $18(10.8 \%)$ & $5(3 \%)$ \\
\hline $\begin{array}{l}\text { A protected source of water can help to } \\
\text { prevent diarrhoea }\end{array}$ & $80(48.2 \%)$ & $57(34.3 \%)$ & $17(10.2 \%)$ & $12(7.2 \%)$ \\
\hline $\begin{array}{l}\text { The use of cup and spoon child feeding } \\
\text { method can help to prevent diarrhoea }\end{array}$ & $95(57.2 \%)$ & $60(36.1 \%)$ & $0(0 \%)$ & $11(6.6 \%)$ \\
\hline
\end{tabular}

\section{Table 4b: Level of health belief of the Prevention Childhood Diarrhoea $(n=166)$}

This study asked questions relating to the health belief of the prevention of Childhood diarrhoea among mothers of under-five children. The result presents the summary of health beliefs of the prevention of Childhood diarrhoea across predisposing factors, reinforcing factors, enabling factors and environmental factors. The mean score for reinforcing factor is $9.89 \pm 3.14$, for predisposing factor is $12.03 \pm 2.09$, enabling factors $7.93 \pm 3.09$ and environmental factor as 12.3 \pm 3.59 . The maximum score obtainable from all the factors is $16,18,14$ and 18 respectively. Across all the factors, there was a moderate level of health belief in the prevention of childhood diarrhoea among the nursing mothers of under-five children.

\begin{tabular}{|c|c|c|c|}
\hline Category & Predisposing factor & Frequency & $\%$ \\
\hline $11-16$ & High & 68 & 41.0 \\
\hline $6-10$ & Moderate & 55 & 33.1 \\
\hline $1-5$ & Low & 43 & 25.9 \\
\hline \multicolumn{4}{|c|}{ Mean $=12.03$, Std. Dev $=2.09$} \\
\hline & Reinforcing factors & & \\
\hline $13-18$ & High & 56 & 33.7 \\
\hline $7-12$ & Moderate & 63 & 38.0 \\
\hline \multirow[t]{3}{*}{$1-6$} & Low & 47 & 28.3 \\
\hline & \multicolumn{3}{|c|}{ Mean =9.89, Std. Dev = 3.14} \\
\hline & Enabling Factor & & \\
\hline $9-14$ & High & 53 & 31.9 \\
\hline $5-8$ & Moderate & 100 & 60.2 \\
\hline \multirow[t]{3}{*}{$1-4$} & Low & 13 & 7.8 \\
\hline & \multicolumn{3}{|c|}{ Mean =7.93, Std. Dev = 3.09 } \\
\hline & $\begin{array}{c}\text { Environmental } \\
\text { Factor }\end{array}$ & & \\
\hline $13-18$ & High & 69 & 41.6 \\
\hline
\end{tabular}




\begin{tabular}{l|l|l|l|}
\hline \multicolumn{1}{|c|}{$7-12$} & \multicolumn{1}{|c|}{ Moderate } & 61 & 36.7 \\
\hline $1-6$ & \multicolumn{1}{|c|}{ Low } & 36 & 21.7 \\
\hline \multicolumn{4}{|c|}{ Mean =12.3, Std. Dev = 3.58 } \\
Keys: Poor: & $<50 \%$ \\
Average: & $50-70 \%$ & & \\
Good: & $71-90 \%$ & & \\
\end{tabular}

Table 5: Management of Childhood diarrhoea in under-five children among nursing mothers in FMC, Owo among nursing mothers $(n=166)$

\begin{tabular}{|l|l|l|l|l|}
\hline Management of Diarrhoea & $\begin{array}{l}\text { Strongly } \\
\text { Agree }\end{array}$ & Agree & Disagree & $\begin{array}{l}\text { Strongly } \\
\text { Disagree }\end{array}$ \\
\hline $\begin{array}{l}\text { I exclude the child from other children to } \\
\text { avoid transmission of diarrhoea }\end{array}$ & $55(33.1 \%)$ & $78(47 \%)$ & $27(16.3 \%)$ & $6(3.6 \%)$ \\
\hline $\begin{array}{l}\text { I give my child both Zinc and ORS to } \\
\text { manage diarrhoea }\end{array}$ & $45(27.1 \%)$ & $76(45.8 \%)$ & $27(16.3 \%)$ & $18(10.8 \%)$ \\
\hline $\begin{array}{l}\text { I apply ORS alone whenever there is a child } \\
\text { with diarrhoea }\end{array}$ & $50(30.1 \%)$ & $74(44.6 \%)$ & $24(14.5 \%)$ & $18(10.8 \%)$ \\
\hline I apply drugs at home without prescription & $48(28.9 \%)$ & $60(36.1 \%)$ & $37(22.3 \%)$ & $21(12.7 \%)$ \\
\hline $\begin{array}{l}\text { I use exclusive breastfeeding for diarrhoea } \\
\text { management }\end{array}$ & $44(26.5 \%)$ & $48(28.9 \%)$ & $46(27.7 \%)$ & $28(16.9 \%)$ \\
\hline ORS prevents dehydration & $47(28.3 \%)$ & $34(20.5 \%)$ & $43(25.9 \%)$ & $42(25.3 \%)$ \\
\hline My child does not like the taste of ORS & $30(18.1 \%)$ & $47(28.3 \%)$ & $59(35.5 \%)$ & $30(18.1 \%)$ \\
\hline $\begin{array}{l}\text { I give my child water when there is case of } \\
\text { diarrhoea because I cannot afford getting } \\
\text { drugs at the pharmacy }\end{array}$ & $67(40.4 \%)$ & $54(32.5 \%)$ & $21(12.7 \%)$ & $24(14.5 \%)$ \\
\hline $\begin{array}{l}\text { I decided not to include salt and water in } \\
\text { the management of diarrhoea }\end{array}$ & $54(32.5 \%)$ & $83(50 \%)$ & $23(13.9 \%)$ & $6(3.6 \%)$ \\
\hline $\begin{array}{l}\text { I approach a nearby chemist for drugs to } \\
\text { manage diarrhoea }\end{array}$ & $28(16.9 \%)$ & $74(44.6 \%)$ & $46(27.7 \%)$ & $18(10.8 \%)$ \\
\hline
\end{tabular}

Table 5b: Level of Management of Childhood diarrhoea (mean score)

\begin{tabular}{|l|c|l|l|l|l|}
\hline Variable & $\begin{array}{l}\text { Maximum Point } \\
\text { on Scale of } \\
\text { Measurement }\end{array}$ & Mean & $\mathbf{\pm S D}$ & $\begin{array}{l}\text { Overall } \\
\text { Percentage }\end{array}$ & $\begin{array}{l}\text { Verbal } \\
\text { Interpretation }\end{array}$ \\
\hline $\begin{array}{l}\text { Level of management of } \\
\text { childhood diarrhoea }\end{array}$ & 29 & 21.9 & 4.46 & 66.4 & $\begin{array}{l}\text { Average level of } \\
\text { management }\end{array}$ \\
\hline
\end{tabular}

Keys:

Below Average: $\quad<50 \%$

Average: $\quad 50-70 \%$

Good: $\quad 71-90 \%$ : 


\section{Test of Hypotheses}

Two hypotheses were tested to examine the relationship of socio-demographic characteristics and prevention of childhood diarrhoea among nursing mothers in under-five children in FMC, Owo and also explore the relationship of knowledge and management of childhood diarrhoea among nursing mothers in under-five children in FMC, Owo. All statistical tests were set at $\mathrm{p}=0.05$ level of significance as cut off. The decision rule applied indicated that the null hypothesis will be rejected in favour of the research hypothesis if the computed p-value is lesser or equal to 0.005 i.e. $\mathrm{p} \leq 0.05$.

Hypothesis one: There was a significant relationship of socio-demographic characteristics and prevention of childhood diarrhoea among nursing mothers in under-five children in FMC, Owo.

The result of cross tabulation and Pearson correlation coefficient showed that there was relationship between mother's socio-demographic characteristics (Marital Status, 0.625, Occupation, 0.788, income of mother, 0.911, ethnicity, 0.771 and level of education, 0.604) and the prevention of childhood diarrhoea, this was significant 0.05 level of significance. However, religion was not significantly related with the prevention of childhood diarrhoea and prevention of childhood diarrhoea among nursing mothers of under-five children in FMC, Owo $(\mathrm{p}>0.05)$. This is represented in Table 6

Table 6: Cross Tabulation showing the relationship between Mothers' socio-demographic characteristics and prevention of childhood diarrhoea among nursing mothers in underfive children in FMC, Owo

\begin{tabular}{|c|c|c|c|c|c|}
\hline \multirow[t]{2}{*}{$\begin{array}{l}\text { Socio-demographic } \\
\text { characteristics }\end{array}$} & \multicolumn{3}{|c|}{$\begin{array}{c}\text { Level of Prevention of } \\
\text { Childhood diarrhoea }\end{array}$} & \multirow[t]{2}{*}{ Total } & \multirow[t]{2}{*}{ r (p-value) } \\
\hline & Good & Fair & Low & & \\
\hline \multicolumn{6}{|c|}{ Marital Status of mother } \\
\hline \multirow{2}{*}{ Single } & 19 & 6 & 3 & 28 & \multirow{4}{*}{$\begin{array}{c}0.625 \\
0.001 * *\end{array}$} \\
\hline & $19.6 \%$ & $12.0 \%$ & $15.8 \%$ & $16.9 \%$ & \\
\hline \multirow[t]{2}{*}{ Married } & 78 & 44 & 16 & 138 & \\
\hline & $80.4 \%$ & $88.0 \%$ & $84.2 \%$ & $83.1 \%$ & \\
\hline \multicolumn{6}{|c|}{ Occupation of mother } \\
\hline \multirow[t]{2}{*}{ Civil servants } & 7 & 6 & 1 & 14 & \multirow{10}{*}{$\begin{array}{c}0.788 \\
0.000 * *\end{array}$} \\
\hline & $7.2 \%$ & $12.0 \%$ & $5.3 \%$ & $8.4 \%$ & \\
\hline \multirow[t]{2}{*}{ Unemployed } & 12 & 6 & 4 & 22 & \\
\hline & $12.4 \%$ & $12.0 \%$ & $21.1 \%$ & $13.3 \%$ & \\
\hline \multirow[t]{2}{*}{ Artisan } & 10 & 6 & 1 & 17 & \\
\hline & $10.3 \%$ & $12.0 \%$ & $5.3 \%$ & $10.2 \%$ & \\
\hline \multirow[t]{2}{*}{ Others } & 32 & 14 & 8 & 54 & \\
\hline & $33.0 \%$ & $28.0 \%$ & $42.1 \%$ & $32.5 \%$ & \\
\hline \multirow[t]{2}{*}{ Trading } & 36 & 18 & 5 & 59 & \\
\hline & $37.1 \%$ & $36.0 \%$ & $26.3 \%$ & $35.5 \%$ & \\
\hline
\end{tabular}




\begin{tabular}{|c|c|c|c|c|c|}
\hline $\begin{array}{l}\text { Income level of mother } \\
\text { per annum }\end{array}$ & & & & & \\
\hline \multirow{2}{*}{ less than 100,000} & 28 & 18 & 5 & 51 & \multirow{6}{*}{$\begin{array}{c}0.911 \\
0.010^{*}\end{array}$} \\
\hline & $28.9 \%$ & $36.0 \%$ & $26.3 \%$ & $30.7 \%$ & \\
\hline \multirow{2}{*}{$100,000-200,000$} & 39 & 14 & 8 & 61 & \\
\hline & $40.2 \%$ & $28.0 \%$ & $42.1 \%$ & $36.7 \%$ & \\
\hline \multirow[t]{2}{*}{ 200,000 Naira above } & 30 & 18 & 6 & 54 & \\
\hline & $30.9 \%$ & $36.0 \%$ & $31.6 \%$ & $32.5 \%$ & \\
\hline \multicolumn{6}{|l|}{ Religion } \\
\hline \multirow[t]{2}{*}{ Christian } & 58 & 36 & 11 & 105 & \multirow{4}{*}{$\begin{array}{l}0.851 \\
0.033\end{array}$} \\
\hline & $59.8 \%$ & $72.0 \%$ & $57.9 \%$ & $63.3 \%$ & \\
\hline \multirow[t]{2}{*}{ Islam } & 39 & 14 & 8 & 61 & \\
\hline & $40.2 \%$ & $28.0 \%$ & $42.1 \%$ & $36.7 \%$ & \\
\hline \multicolumn{6}{|l|}{ Ethnicity } \\
\hline \multirow[t]{2}{*}{ Yoruba } & 78 & 44 & 16 & 138 & \multirow{4}{*}{$\begin{array}{c}0.771 \\
0.000^{*}\end{array}$} \\
\hline & $80.4 \%$ & $88.0 \%$ & $84.2 \%$ & $83.1 \%$ & \\
\hline \multirow[t]{2}{*}{ Igbo } & 19 & 6 & 3 & 28 & \\
\hline & $19.6 \%$ & $12.0 \%$ & $15.8 \%$ & $16.9 \%$ & \\
\hline \multicolumn{6}{|l|}{ Educational Level } \\
\hline \multirow[t]{2}{*}{ No formal education } & 40 & 28 & 15 & 83 & \multirow{8}{*}{$\begin{array}{c}0.604 \\
0.000^{*}\end{array}$} \\
\hline & $41.2 \%$ & $56.0 \%$ & $78.9 \%$ & $50.0 \%$ & \\
\hline \multirow[t]{2}{*}{ Primary education } & 15 & 6 & 3 & 24 & \\
\hline & $15.5 \%$ & $12.0 \%$ & $15.8 \%$ & $14.5 \%$ & \\
\hline \multirow[t]{2}{*}{ secondary education } & 35 & 12 & 0 & 47 & \\
\hline & $36.1 \%$ & $24.0 \%$ & $0.0 \%$ & $28.3 \%$ & \\
\hline \multirow[t]{2}{*}{ Tertiary education } & 7 & 4 & 1 & 12 & \\
\hline & $7.2 \%$ & $8.0 \%$ & $5.3 \%$ & $7.2 \%$ & \\
\hline
\end{tabular}

**. Correlation is significant at the 0.05 level (2-tailed)

Hypothesis two: There was a significant relationship of knowledge and management of childhood diarrhoea among nursing mothers of under-five children in FMC, Owo

Table 7: Pearson Product Moment correlation showing the relationship between knowledge and management of childhood diarrhoea among nursing mother of under-five children

\begin{tabular}{|c|c|c|c|c|c|c|}
\hline Variables & Mean & $\begin{array}{l}\text { Standard } \\
\text { Deviation }\end{array}$ & $\mathbf{N}$ & $\mathbf{r}$ & $\mathbf{p}$ & Decision \\
\hline $\begin{array}{l}\text { Knowledge of } \\
\text { diarrhoea }\end{array}$ & $\begin{array}{r}10.331 \\
3 \\
\end{array}$ & 1.73865 & \multirow[t]{2}{*}{166} & \multirow[t]{2}{*}{0.779} & \multirow[t]{2}{*}{0.05} & \multirow[t]{2}{*}{ Sig } \\
\hline $\begin{array}{l}\text { Management of Childhood } \\
\text { diarrhoea }\end{array}$ & $\begin{array}{r}21.849 \\
4\end{array}$ & 4.46212 & & & & \\
\hline
\end{tabular}

$$
r=0.779 N=166, p<0.05
$$


From the result presented in the table above which revealed that, there is a significant relationship between knowledge and management of childhood diarrhoea among nursing mothers of under-five children in FMC, Owo $(r=0.779, \mathrm{df}=165, \mathrm{p}<0.05)$. The result rejected the null hypothesis and accepted the alternate hypothesis, which states that, there was a significant relationship between knowledge and management of childhood diarrhoea among nursing mothers of under-five children in FMC, Owo.

\section{DISCUSSION OF FINDINGS}

\section{Level of Knowledge Childhood Diarrhoea}

The result of research question one indicated that more than half of the mothers have average knowledge of childhood diarrhoea, $30.1 \%$ had good knowledge while $11.5 \%$ had poor level of knowledge of childhood diarrhoea. The result of the analysis is consistent with the findings of Bello (2019) about how knowledge and practice of adequate and quality childhood care could lead to healthiness of the child in terms of prevention of early childhood diseases while lack of knowledge and poor practices increase the chances of prevalence of childhood diseases. The result is in tandem with the findings of Arulogun (2018) that place great emphasis on the importance of children getting a good start in life, for future growth and development in cognitive and pscho-social terms as well as physically. Additionally, Park (2019) opined that the great majority of mothers have little knowledge of nutritional value of breast milk or of the health risks of early exposure to other liquids and solids, leading to one of the main causes of diarrhoea in young children, which can set off a vicious cycle of illness and malnutrition. Similarly, Alaba \& Agba (2018) stated that knowledge is desirable among mothers including those of Ezeagu LGA;mothers have been traditionally recognized to be responsible for the health care of their children and other members of the family.

\section{Level of health belief of the Prevention Childhood Diarrhoea}

The result of research two showed that across all the factors there was a moderate level of health belief of the prevention of childhood diarrhoea among the nursing mothers of under-five children. The result is supported with findings of Mouskin and Miller (2016) stating that it is essential to determine both the extent and quality of knowledge that a person has about a particular issue. This, according to them, is because knowledge is instrumental in accepting or resisting any change. Mba (2018) argued that one of man's greatest enemies is ignorance. He maintained that knowledge will give one necessary power and put one in the appropriate frame of mind for positive attitude and practice. Winifred (2019) is accumulated facts, truths, principles and information to which the human mind has access. Jelliffe \& Jelliffe (2016) asserted that the beliefs concerning the cause of diarrhoea vary widely in different cultures. They explained that diarrhoea may be considered to result from normal developmental events in young children (e.g. teething, crawling) or from eating certain foods, perhaps because of the special properties of those foods (e.g. hot or cold foods). Mellinda (2018) on the effect of oral rehydration solution (ORS) and recommended home fluids (RHFs) on diarrhoea mortality showed that ORS may reduce diarrhoea mortality by up to $93 \%$ in home, community and facility settings. However, it is very important to make use of ORS that is correctly prepared. In countries with high-mortality due to diarrhoea such as Nigeria, the prevailing practice among mothers is to seek treatment from private retailers such as pharmacies and drug shops. 


\section{Research Question three: Management of Childhood diarrhoea in under-five children}

The result of the research question three showed that there was an average level of management of Childhood diarrhoea which gave significant reason for the increasing incidences of childhood diarrhoea. The result corroborates with the findings of Meneses, Bernard \& Pelto (2016) on the selection of culturally sound fluid management of infantile diarrhoea. The study further showed that Mclennan's (2018) management of childhood diarrhoea reduces the prevalence of childhood diarrhoea especially in poor urban regions of the Domincan countries where resources are limited. The study is also supported with the findings that Strivasta \& Ramsel (2016) conducted on the study of the utilization of health services. The objective of the study was to determine the association between education and utilization of health measures.

Hypothesis one: There was a significant relationship of socio-demographic characteristics and prevention of childhood diarrhoea among nursing mothers in under-five children in FMC, Owo. The result is consistent with the findings of Coreil \& Genece (2018) on the demographic characteristics associated with the level of preventing childhood diarrhoea in children among the nursing mothers of under-five children residing in developing countries in Trinidad and Tobago. Furthermore, Foote (2019) made an evaluation before and after an intensive mass media campaign about the knowledge of childhood diarrhoea and ORT with the aim of finding significant associations between knowledge of ORT and exposure to the campaign. Population Report (2015) showed that age, parity, educational level, location and employment had major influence on utilization of health services. According to the report, there was a high use rate amongst women aged $30-39$ years and least among women aged below 30 years. The use rate was also high among women with 2 to 3 children, better - educated women and among urban women. Additionally, Jelliffe \& Jelliffe (2016) asserted that the demographic features of mothers influence prevention of diarrhoea in under-five children. They explained that diarrhoea may be considered to result from normal developmental events in young children (e.g. teething, crawling) or from eating certain foods, perhaps because of the special properties of those foods (e.g. hot or cold foods).

\section{CONCLUSION AND RECOMMENDATION}

Managing diarrhoea at home is quite common among rural mothers, but their level of knowledge is poor. Perception of the seriousness of diarrhoea or other health related conditions is a paramount factor for seeking healthcare. There is a practice of reducing and even stopping fluids during diarrhoea. Regrettably, in spite of the knowledge gained by these mothers, childhood diarrhoea is found to be the second main cause of under-five mortality the world over, in the developing countries and in Nigeria in particular.

In view of the above findings and conclusion, the following recommendations were made:

1. There is a need for public health physicians, social workers to provide nutritional educational programs about diarrhoea should be implemented for mothers in different community health services .

2. Government should enforce good sanitation and improvement of housing conditions, especially water resources in rural areas. 
3. There is a need for posters to be posted in outpatient clinics to enhance the practice used in management of diarrhoeal disease.

4. Public health physicians should create materials about the practical procedures that could be useful in teaching mothers required skills such as Oral rehydration solution preparation and how to give to their children.

\section{REFERENCES}

Abass, G.A (2017) Knowledge, Attitude and Practice of Home Management of Childhood Diarrhoea among Caregivers of Under-5 Children with Diarrhoeal Disease in Northwestern Nigeria. Journal of Tropic Pediatric. Available from: http://tropej.oxfordjournals.org/content/early. Accessed: April 2015

Adebayo, R.O (2018) Knowledge, Perception, and Management Skills of Mothers with Under-five Children about Diarrhoea Disease in Indigenous and Resettlement Communities in Assosa District, Western Ethiopia. Journal of Health Popul Nutr. 2015;33(1):20-30.

Alaba, A.O., \& Agba, M.J (2018) Changing poor mothers' care-seeking behaviors in response to childhood illness: findings from a cross-sectional study in Granada, Nicaragua. BMC International Health and Human Rights, 10, 10. doi:10.1186/1472-698X-10-10

Andrade, B (2019) Children who were vaccinated, breast fed and from low parity mothers live longer: a community based case-control study in Jimma, Ethiopia. BMC Public Health, 11(1), 1. doi:10.1186/1471-2458-11-197

Arulogun, T.A (2018) Knowledge of Mothers in MAnagement of Diarrhoea in Under 5 Children in Kashan ,Iran. Nurs Midwifery stud, pp. 158-62.

Breurec, A.O (2017) Food and personal hygiene perceptions and practices among caregivers whose children have diarrhoea: A qualitative study of urban mothers in tangerang. Indonesia J Nut Edu Behav, Vol. 24 No. 6, pp. 417-429

Coreil, A.S., \& Genece, A.F (2018) Effect of zinc supplementation in children with acute diarrhoea: Randomized double blind controlled trial. Gastroenterology Res, 2(3), 168174. doi: $10.4021 / \mathrm{gr} 2009.06 .1298$

Foote, A.A (2019) Home based management of acute diarrhoeal disease in an urban slum of Aligarh ,India . Journal of infectious Dev Cities, 137-42.

Jelliffe, A.M \& Jelliffe, O.O (2016) A survey of mothers' knowledge about childhood diarrhoea and its management among a marginalised community of Morang,Nepal. Australasian Medical Journal, 4(9), 474-479. doi:http://doi.org/10.40

Jelliffe, T.O., \& Jelliffe, L.P (2016) Global burden of childhood pneumonia and diarrhoea. Lancet, 9875, 1405-16. doi: 10.1016/S0140-6736(13)60222-6

Kotlof, F.A (2019) Infant feeding practices and diarrhoea in sub-Saharan African countries with high diarrhoea mortality. PLoS ONE, 12(2), e0171792. doi:https://doi.org/10.1371/journal.pone.0171792

Lanata, A (2019) Measuring coverage in MNCH: Tracking progress in health for women and children using DHS and MICS household surveys. PLoS Med, 10(5), e1001391. doi:10.1371/journal.pmed.1001391

Mansur, T.O (2017) What's for Lunch?: A Socio-ecological Approach to Childcare Nutrition. In Proceedings of the 2016 ACM Conference on Designing Interactive Systems (pp. 11601171). ACM. doi:10.1145/2901790.2901793 
Mba, L.A (2018) Breastfeeding and the risk for diarrhea morbidity and mortality. BMC Public Health, 11(3), S15. doi:10.1186/1471-2458-11-S3-S15

Mclennan, Y.O., (2018) Gaps in policy -relevant information on burden of children :A systematic review. Lancet, 365, 2031-2040.

Mellinda, T.O (2018) Risk factors for predicting diarrheal duration and morbidity in children with acute diarrhea. Indian J Pediatr., 79(4):472-7.

Meneses, J.A., Bernard, A.D., \& Pelto, R.O (2016) Pathogen-specific burdens of community diarrhoea in developing countries: a multisite birth cohort study (MAL-ED). The Lancet Global health, 3(9), e564-e575.

Mouskin, A.S \& Miller, A.O (2016) Knowledge and perception of mothers and caregivers on childhood diarrhoea and its management in Temeke Municipality ,Tanzania. Tanzania Journal of Health Research, 12(1), 47-54.

Park, J.G (2019) Contributions to the Discovery of Clostridium difficile Antibiotic-Associated Diarrhoea. Clinical Infectious Diseases, 59(2), S66-S70.

Population Report (2015) Food and personal hygiene perceptions and practices among caregivers whose children have diarrhoea:a qualitative study of urban mothers in Nigeria. Population Report. Abuja

Solar, D (2017) Burden and aetiology of diarrhoeal disease in infants and young children in developing countries (the Global Enteric MulticenterStudy, GEMS): A prospective, casecontrol study. The Lancet.; 382(9888):209-2

Strivasta, A.D., \& Ramsel, U.O (2016) Pattern of Maternal Knowledge and Its Implications for Diarrhoea Control in Southern Malawi: Multilevel Thresholds of Change Analysis. Int J Environ Res Public Health, 9(3), 955-969. doi:10.3390/ijerph9030955

Suk, A.O (2016) Hospital nurses' work environment, quality of care provided and career plans. International Nursing Review, Vol. 7 (3), pp. 351-361

UNICEF, (2019) Pneumonia and Diarrhoea: Tackling the Deadliest Diseases for the World's Poorest Children. New York: UNICEF

WHO/UNICEF, (2019) Childhood diarrhea prevalence in Nigeria. Abuja.

Winifred, A.R.P (2019) Human-milk glycans that inhibit pathogen binding protect breastfeeding infants against infectious diarrhea. Journal of Nutrition, 135, 1304-1307. 